\title{
Mercury complexes of an $N$-heterocyclic carbene derived from a calixarene/azolium cyclophane hybrid ${ }^{\dagger}$
}

Valerie J. Hesler · Brian W. Skelton · Allan H. White · David H. Brown · Murray V. Baker

Received: XX April 2015 / Accepted XX XXX 201X

(C) Springer Science + Business Media Dordrecht 2015

\begin{abstract}
Reaction of mercuric acetate with an imidazolium-linked cyclophane incorporating 2,6-phenolic moieties results in formation of an interesting new $\mathrm{N}$-heterocyclic carbene (NHC) complex of mercury. The new complex is cationic and binuclear, incorporating two mercury centres and two bis(NHC) ligands, each mercury atom being bound by two NHC moieties and two phenol/phenoxy moieties. Forms of the complex having coordinating $\left(\mathrm{HgBr}_{4}^{2-}\right)$ and non-coordinating $\left(\mathrm{PF}_{6}{ }^{-}\right)$ counterions have been structurally characterised.
\end{abstract}

Keywords Cyclophane $\cdot \mathrm{NMR} \cdot \mathrm{X}$-ray crystal structure $\cdot$ Mercury $\cdot N$-Heterocyclic carbene $\cdot$ Calixarene

Dedicated to Jack Harrowfield and Jacques Vicens: 'Nil illegitimae abradum!'

Valerie J. Hesler · Allan H. White · David H. Brown · Murray V. Baker ( $₫$ )

School of Chemistry and Biochemistry M310, The University of Western Australia, Crawley WA 6009 Australia. email: murray.baker@uwa.edu.au

Brian W. Skelton

School of Chemistry and Biochemistry and the Centre for Microscopy, Characterisation, and Analysis M310, The University of Western Australia, Crawley WA 6009 Australia

$\dagger$ To follow: Hesler, V. J., Skelton, B. W., White, A. H., Brown, D. H., Baker, M. V.: Calixarene/azolium cyclophane hybrids: synthesis, structure and conformations. J. Incl. Phenom. Macrocycl. Chem., DOI 10.1007/s10847-015-0491-1 (2015)

Published online: 


\section{Introduction}

$\mathrm{N}$-Heterocyclic carbene (NHC) ligands have been a focal point in organometallic chemistry over the last two decades, in part because of their ability to form stable complexes with many metals. Some NHC complexes in which the NHC components are part of a cyclophane skeleton have proved to be particularly robust, and have exhibited interesting catalytic and biological activities. There has also been much interest in metal complexes of NHCs that have pendant groups that can serve as ancillary hemilabile donors. For example, metal complexes of NHCs having pendant thiolate [1], thioether [2, 3], ether [4, 5], alkoxide [6, 7], phenol [8] and phenoxide [9-13] moieties have been reported, and in some of those studies their catalytic activities have been explored.

In a previous report [14], we explored the nature of compounds $1.4 \mathrm{PF}_{6}-\mathbf{4}$ formed between mercury(II) and bis(NHC) ligands derived from imidazolium-linked cyclophanes $5.2 \mathrm{Br}-\mathbf{8} .2 \mathrm{Br}$ (Scheme 1). In the macrocycles, the groups linking the imidazolium/NHC components contained $o$ phenylene (e.g., 1.4PF 6 , 5.2Br), $m$-phenylene (e.g., 2.2PF, $6.2 \mathrm{Br}$ ), mesityl (e.g., 3.2PF, $7.2 \mathrm{Br}$ ) or 2,6-pyridinediyl moieties (e.g., 4, 8.2Br). Among the complexes, $\mathbf{2}^{2+}$ and $\mathbf{3}^{2+}$ were mononuclear species, while $\mathbf{1}^{4+}$ and 4 were binuclear; the macrocycle in $1.4 \mathrm{PF}_{6}$ and $\mathbf{5} .2 \mathrm{Br}$ is fourteen-membered, and sixteen-membered in $2.2 \mathrm{PF}_{6}-4$ and $6.2 \mathrm{Br}-\mathbf{8} .2 \mathrm{Br}$. In $2^{2+}$ and $3^{2+}$, the mercury atom is quasilinearly coordinated by a pair of carbene-carbon atoms, the heterocyclic rings of the NHC units being essentially coplanar. Despite the mercury atoms in $\mathbf{2}^{2+}$ and $\mathbf{3}^{2+}$ having additional long piinteractions with the bridging aromatic groups to either side, we find one or two distant approaches in the remaining fifth (and sixth) coordination positions by anionic (hexafluorophosphate) fluorine atoms. In $\mathbf{1}^{4+}$ and $\mathbf{4}$, the still quasi-linearly coordinating carbenoid carbon atoms are drawn from different macrocycles, the mercury atom coordination environments now being augmented by (still rather distant) solvent DMSO O-donors (rather than $\mathrm{PF}_{6}{ }^{-}$counterions) in $\mathbf{1}^{4+}$, and, in $\mathbf{4}$, by pairs of bromide ions (rather than the accompanying DMSO solvent). 
In the preceding contribution [15], we explored a further macrocycle $\mathbf{9}^{2+}$ (Scheme 1) in which the azolium cyclophane form was combined with the calix[4]arene form (which has certain similarities). Here, the imidazolium rings are now coupled with 2,6-phenolic linkages, the latter functionalized and potential donors (cf. the pyridine cyclophane $\mathbf{8}^{2+}$, and its NHC derivative in $\mathbf{4}$, wherein any potential interaction of the potential pyridine donor with mercury was obviated by the presence of the coordinated bromide); in $\mathbf{9}^{2+}$, the macrocycle is the same size as in the pyridinelinked $\mathbf{8}^{2+}$. Arguably, however, the coordination propensity of the phenolic oxygen atom may be increased by virtue of its pendant nature, assisted by its enhanced its proximity to any receptor metal atom. In this paper, we explore this possibility via the synthesis and structural characterisation of two salts of a mercury(II) complex of the bis(NHC) ligand derived from $\mathbf{9}^{2+}$.

\section{Results and discussion}

Synthesis and NMR studies

Treatment of the cyclophane salt $9.2 \mathrm{PF}_{6}$ with an equimolar amount of mercuric acetate in acetonitrile at reflux resulted in formation of the binuclear $\mathrm{Hg}-\mathrm{NHC}$ complex $\mathbf{1 0}^{2+}$ (Scheme 2). The complex was obtained as colourless needles of the hexafluorophosphate salt $10.2 \mathrm{PF}_{6}$, which was easily purified by recrystallisation from acetonitrile. Unequivocal identification of the structure of the complex $\mathbf{1 0}^{2+}$ required an X-ray study (see below). Nevertheless, formation of an $\mathrm{Hg}-\mathrm{NHC}$ complex was confirmed by ${ }^{1} \mathrm{H}$ NMR spectroscopy, by loss of the signal due to the imidazolium $\mathrm{H} 2$ protons of $9^{2+}(\sim 8.6 \mathrm{ppm}$, Fig. 1a), as well as loss of the broad singlet due to the benzylic protons in $9^{2+}$ and the appearance of two sharp doublet signals corresponding to benzylic protons in chemically distinct exo and endo environments in the complex $\mathbf{1}^{2+}(\sim 4.9$ and $6.0 \mathrm{ppm}$, Fig. 1b). No signal due to the phenolic protons in $\mathbf{1 0}^{2+}$ was detected, perhaps because of rapid exchange of the phenolic protons between sites on phenolic oxygen atoms in $\mathbf{1 0}^{2+}$ and sites in adventitious water,= 
or hydrogen-bound to solvent ( $\mathrm{d}_{6}$-DMSO) molecules. Consistent with this suggestion, the signal for adventitious water $(\sim 3.3 \mathrm{ppm}$, Fig. $1 \mathrm{~b})$ is somewhat broadened. In the ${ }^{13} \mathrm{C}$ NMR spectrum, the signal due to the $\mathrm{Hg}-\mathrm{C}$ carbon atoms appears near $174 \mathrm{ppm}$.

Complex $\mathbf{1 0}^{2+}$ was also formed when $9.2 \mathrm{Br}$ or the binuclear salt 11.2Br [15] (Scheme 3) were heated with mercuric acetate in DMF or acetonitrile respectively. From one such experiment, the complex crystallised from DMF as $\mathbf{1 0 .} \mathrm{HgBr}_{4}$, an adduct with tetrabromidomercurate (see below). The ${ }^{1} \mathrm{H}$ NMR spectra of solutions containing $10 . \mathrm{HgBr}_{4}$ or $10.2 \mathrm{PF}_{6}$ were essentially identical, suggesting little if any interaction between $\mathbf{1 0}^{2+}$ and the counteranions in solution.

We conducted a few experiments aimed at synthesizing complexes of other metals with NHC ligands derived from $\mathbf{9}^{2+}$. When $\mathbf{9 . 2 B r}$ was treated with titanium(IV) tetra(isopropoxide) in THF at reflux, no reaction occurred. When $9.2 \mathrm{Br}$ was treated with silver(I) oxide in DMF or copper(I) oxide in $\mathrm{CH}_{2} \mathrm{Cl}_{2}, \mathbf{9}^{2+}$ was partially deprotonated, to form the dimeric cation $\mathbf{1 1}^{2+}$ [15], which was identified by ${ }^{1} \mathrm{H}$ NMR spectroscopy, but no evidence for metal complexes was seen. We also explored the possibility of preparing metal complexes from NHC ligands derived from the hexafluorophosphate salt of the mono-phenol imidazolium cyclophane $\mathbf{1 2}^{2+}$ (Scheme 3 ). When 12.2 $\mathrm{PF}_{6}$ was treated with mercuric acetate in acetonitrile at reflux, there was no significant reaction. When $12.2 \mathrm{PF}_{6}$ was treated with silver oxide in acetonitrile at reflux, or when $12.2 \mathrm{Br}$ was treated with palladium acetate in DMF at $90{ }^{\circ} \mathrm{C}$ overnight or at room temperature for 3 days, intractable mixtures were obtained. Examination of the product mixtures by ${ }^{1} \mathrm{H}$ NMR spectroscopy provided no evidence for formation of discrete complexes, and the presence of very broad signals suggested that polymeric products may have been formed.

\section{Structural Studies}

Two crystalline compounds were obtained from solutions of $10.2 \mathrm{PF}_{6}$ and $\mathbf{1 0 .} \mathrm{HgBr}_{4}$ in acetonitrile and DMF respectively. The results of the 'low'-temperature single crystal X-ray studies (Tables 1 - 3 
and Fig. 2) are consistent with the descriptions of the compounds and their structures as solvated salts of the same cation, the latter being binuclear and of putative $\mathrm{mmm} 2 / \mathrm{m}\left(C_{2 \mathrm{~h}}\right)$ symmetry, modelled as $10.2 \mathrm{PF}_{6} \cdot 5 \mathrm{MeCN}$ and $10 . \mathrm{HgBr}_{4} \cdot 8 \mathrm{DMF}$; a single one of these formulations, differing in the associated cation symmetry, comprises the asymmetric unit of structure in each case. The presence of core protonation is presumed from the chemistry in each case, none of the hydroxylic hydrogen atom locations being secured from the structure determinations, either from difference syntheses, or from associated phenolic C-O distances which are closely similar; Hg-O (distances) and $\mathrm{Hg}-\mathrm{O}-\mathrm{C}$ (angles) ranges (the latter very tight) (Table 2) are similarly unhelpful (but see below). In the $\mathrm{PF}_{6}^{-}$salt, one of the $\mathrm{PF}_{6}$ groups (\#2) was modelled as rotationally disordered over two sets of sites about one of its local F-P-F axes, occupancies 0.73(2) and complement. In the $\mathrm{HgBr}_{4}{ }^{2-}$ salt, two of the ligand t-Bu groups $(\# 13,23)$ were modelled as rotationally disordered over two sets of sites, occupancies set at 0.692(13), 0.5 and complements after trial refinement; two DMF groups (one closely approaching a cation mercury atom, ('coordinated'), one not), were modelled as disordered over pairs of sites in concert with the t-Bu groups.

In each case, the form of the cation comprises a pair of ligands, each grossly in a 'cone' conformation, approaching each other in 'eclipsed' confrontation about a common axis, so that their carbenoid carbon atoms confront pairwise, each pair linearly coordinating a mercury atom at ca. 2.0 $\AA$ (Table 2), so that a binuclear array is formed. The C-Hg-C linearity is not exact, bowing of the C-Hg-C lines being associated with mutual approaches of the pair of mercury atoms to ca. $4.8 \AA$, the $\mathrm{C}_{2} \mathrm{Hg}_{2} \mathrm{C}_{2}$ array being quasi-planar (Fig. 2). The coordination environments of the mercury atoms are further augmented by interactions with two phenolic oxygen atoms from the same ligand; each ligand thus contributes a coordination triad of $(\mathrm{C})(\mathrm{O})_{2}$ to one mercury atom, with the other carbenoid carbon to the other. To either side of the $\mathrm{C}_{2} \mathrm{Hg}_{2} \mathrm{C}_{2}$ plane, pairs of oxygen atoms, one pair from each of the ligands, approach at a distance ca. $2.5 \AA$, appropriate to the support of a pair of appropriately protonating putative hydrogen atoms between the pairs, consistent with a $2+$ cationic 
charge overall, counterbalancing the $\mathrm{PF}_{6}^{-}$or $\mathrm{HgBr}_{4}{ }^{2-}$ anion array (Fig. 2). One possible protonic hydrogen disposition is shown in Fig. 2b; others, symmetrical or not, are also possible.

In respect of the anions and solvent molecules in the $\mathrm{PF}_{6}^{-}$salt, there appear to be no close approaches (coordinative) to the mercury atom, or interactions with ligand aromatic rings within or without the ligand cones. There are two centrosymmetric arrays (e.g., Fig. 2a), one-half of each contributing to the asymmetric unit of the structure, so that, with a pair of $\mathrm{PF}_{6}^{-}$anions and five acetonitrile molecules, one such formula unit comprises the contents of the unit cell, the arrays being essentially 'naked', cf. (e.g.) those of the compounds $1.4 \mathrm{PF}_{6}$ and 4 [14].

The array of the $\mathrm{HgBr}_{4}{ }^{2-}$ salt is a different matter. Here the two mercury atoms within the single binuclear cation of the asymmetric unit are crystallographically distinct, and, despite the presence of similar bowings of the $\mathrm{C}-\mathrm{Hg}-\mathrm{C}$ lines to those found in the $\mathrm{PF}_{6}{ }^{-}$salt, there are pairs of approaches, from the oxygen atoms of two of the solvating DMF molecules to $\operatorname{Hg}(2)$, and two of the bromine atoms of an $\mathrm{HgBr}_{4}{ }^{2-}$ anion to $\mathrm{Hg}(1)$ (at 3.129(8), 3.121(11); 3.5448(12), 3.5208(14) $\AA$ respectively) to putative distant fifth and sixth pseudo-octahedral coordination sites about these atoms (Fig. 2 b). It is interesting to compare the mercury environments of $1.2 \mathrm{PF}_{6}$ and 4 with those in $10 . \mathrm{HgBr}_{4} \cdot 8 \mathrm{DMF}$. In both $1.2 \mathrm{PF}_{6}$ and 4 the mercury centres are four-coordinate, the ancillary ligands being purely $O$-bound solvent (DMSO) in $1.2 \mathrm{PF}_{6}$ and bromide (in the presence of DMSO) in 4 [14]. In $10 . \mathrm{HgBr}_{4} \cdot 8 \mathrm{DMF}$, we find, in the six-coordinate environments of the pair of independent mercury atoms, that the enhancement above the $\mathrm{C}_{2} \mathrm{Hg}(\mathrm{O} \text {-phenol })_{2}$ arrays in one case comprises a pair of $c i s$-bromide donors, in the other, a pair of $c i s-\mathrm{O}-\mathrm{DMF}$. Hg-C,O distances in the case of the bromide coordinated mercury atom are slightly elongated cf. their counterparts in the case of the other (Table 2); $\mathrm{Hg}-\mathrm{O}$ (solvent), $\mathrm{Br}$ in $\mathbf{1 0} \cdot \mathrm{HgBr}_{4} \cdot 8 \mathrm{DMF}$ are considerably longer than their counterparts in compounds $1.4 \mathrm{PF}_{6}$ and 4 [14].

For the cations in both $10.2 \mathrm{PF}_{6} \cdot 5 \mathrm{MeCN}$ and $10 . \mathrm{HgBr}_{4} \cdot 8 \mathrm{DMF}$, 'platform' least-squares planes may be calculated through their mercury and carbene carbon atoms, deviations of the latter 
being not greater than $0.03 \AA$. Dihedral angles between these planes and associated $\mathrm{C}_{6}$ aromatic ring planes are $37.8,39.4(3)^{\circ}\left(\mathrm{PF}_{6}^{-}\right.$salt $)$and $34.3,37.6(2)^{\circ}\left(\mathrm{HgBr}_{4}{ }^{2-}\right.$ salt $)$; deviations of the mercury atoms from the $\mathrm{C}_{6}$ and $\mathrm{C}_{3} \mathrm{~N}_{2}$ ring planes are given in Table 3. The descriptors within Tables 2 and 3 are similar for all of the cations and suggest that the impacts of the coordinating anion and solvent on either of the interacting species in the $\mathrm{HgBr}_{4}{ }^{2-}$ salt are quite limited; the only seriously deviant parameter is perhaps one of the $\mathrm{O}-\mathrm{Hg}-\mathrm{C}$ angles in the $\mathrm{HgBr}_{4}{ }^{2-}$ salt, while, in the $\mathrm{PF}_{6}^{-}$salt, one of the $\mathrm{Hg} . . . \mathrm{Hg}^{\prime}$ distances might be considered somewhat short.

The organizing effect of the introduction of the mercury atoms into the ligand pair is evident in the dihedral angle comparisons which may be made in Table 3. It is seen that those of the present cations are similar between $10.2 \mathrm{PF}_{6} \cdot 5 \mathrm{MeCN}$ and $10 . \mathrm{HgBr}_{4} \cdot 8 \mathrm{DMF}$. For the imidazolium cyclophane salt 11.2Br, the structure of which comprises a symmetry related pair maintained by the hydrogen-bonds alone (without the mercury atoms), the interplanar angle between the pairs of aromatic planes is similar to that of the mercury complexes, whereas the angle between the pair of imidazole planes (which have the perception of random orientation in the free ligand, the more so given the observation of the other isomer [16] wherein they are opposed), is quite different. The hydrogen-bonded $\mathrm{O} . . \mathrm{O}$ distances, assisting the anchoring of the aromatic rings in both ligand and complexes, are similar.

\section{Conclusion}

When mercuric acetate is allowed to react with the calixarene/azolium cyclophane hybrid $\mathbf{9}^{2+}$, an interesting new binuclear complex $\mathbf{1 0}^{2+}$ is formed, the calixarene/azolium cyclophane having been deprotonated at both imidazolium C2 positions and one of the phenolic positions. When the

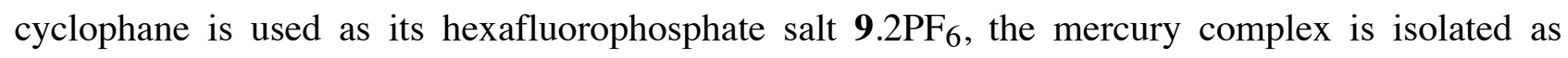
10.2 $\mathrm{PF}_{6}$, and each mercury centre is four-coordinate. When the cyclophane is used as its bromide 
salt 9.2Br, the tetrabromidomercurate ion is formed under the reaction conditions. The binuclear complex $\mathbf{1 0}^{2+}$ crystallises from DMF as a solvate of the tetrabromidomercurate adduct $10 . \mathrm{HgBr}_{4}$, each mercury centre in the cation being six-coordinate, one by virtue of coordination with the $\mathrm{HgBr}_{4}{ }^{2-}$ ion, the other by interactions with $\mathrm{O}$ atoms of two DMF molecules. The binding between $\mathbf{1 0}^{2+}$ and $\mathrm{HgBr}_{4}{ }^{2-}$ does not persist in $\mathrm{d}_{6}$-DMSO solution.

\section{Experimental Section}

General procedures and the synthesis of $9.2 \mathrm{Br}$ were as described previously [15].

Bis(phenol) cyclophane salt 9.2PF6

A filtered solution of potassium hexafluorophosphate $(277 \mathrm{mg}, 1.51 \mathrm{mmol})$ in water $(\mathrm{ca} .3 \mathrm{~mL})$ was added to a solution of $9.2 \mathrm{Br}$ [15] (302 $\mathrm{mg}, 0.47 \mathrm{mmol}$ ) in water (ca. $25 \mathrm{~mL}$ ) and the resulting mixture was stirred at room temperature for $30 \mathrm{~min}$. The precipitate was collected and dried in a desiccator under vacuum for $2 \mathrm{~d}$ to afford a colourless powder $(223 \mathrm{mg}, 61 \%) .{ }^{1} \mathrm{H}$ NMR $(500.13$ MHz d 6 -DMSO): $\delta 1.26\left(\mathrm{~s}, 18 \mathrm{H}, 6 \times \mathrm{CH}_{3}\right), 5.37\left(\mathrm{br} \mathrm{s}, \mathrm{W}_{\mathrm{H} / 2}=16 \mathrm{~Hz}, 8 \mathrm{H}, 4 \times \mathrm{CH}_{2}\right), 7.59(\mathrm{~s}, 4 \mathrm{H}, 4 \mathrm{x}$ ArH), 7.68 (apparent d, splitting $=2 \mathrm{~Hz}, 4 \mathrm{H}, 2 \times \mathrm{H} 4$ and $2 \times \mathrm{H} 5), 8.63\left(\right.$ br s, $\mathrm{W}_{\mathrm{h} / 2}=19 \mathrm{~Hz}, 2 \mathrm{H}, 2 \mathrm{x}$ H2), 9.63 (br s, $\left.\mathrm{W}_{\mathrm{H} / 2}=13 \mathrm{~Hz}, 2 \mathrm{H}, 2 \times \mathrm{OH}\right)$.

Phenol/ortho-cyclophane 12.2PF6

A solution of potassium hexafluorophosphate $(131 \mathrm{mg}, 0.71 \mathrm{mmol})$ in water $(\mathrm{ca} .2 \mathrm{~mL})$ was added to a stirred, filtered solution of $12.2 \mathrm{Br}(101 \mathrm{mg}, 0.18 \mathrm{mmol})$ in water (ca. $5 \mathrm{~mL}$ ) and the resulting mixture was stirred at room temperature for $20 \mathrm{~min}$. The precipitate was collected, washed with water and dried in a vacuum desiccator for $2 \mathrm{~d}$ to afford a white powder (96 mg, 77\%). ${ }^{1} \mathrm{H}$ NMR 
(500.13 MHz, d6-DMSO): $\delta 1.34\left(\mathrm{~s}, 9 \mathrm{H}, 3 \times \mathrm{CH}_{3}\right), 5.17\left(\mathrm{~d},{ }^{2} \mathrm{~J}_{\mathrm{HH}}=14 \mathrm{~Hz}, 2 \mathrm{H}, 2 \mathrm{x} \mathrm{Hb}\right), 5.34(\mathrm{br}$ d, splitting $=14 \mathrm{~Hz}, 2 \mathrm{H}, 2 \times \mathrm{Ha}), 5.54\left(\mathrm{~d},{ }^{2} \mathrm{~J}_{\mathrm{HH}}=14 \mathrm{~Hz}, 2 \mathrm{H}, 2 \mathrm{x} \mathrm{Hb}\right), 5.66\left(\mathrm{~d},{ }^{2} \mathrm{~J}_{\mathrm{HH}}=14 \mathrm{~Hz}, 2 \mathrm{H}, 2 \mathrm{x}\right.$ Ha), 7.60 (AA' part of $\mathrm{AA}^{\prime} \mathrm{XX}$ ' pattern, 2H, 2 x H3a), 7.62 (s, 2H, 2 x H5), 7.81 (s, 2H, 2 x H4), $7.81(\mathrm{~s}, 2 \mathrm{H}, 2 \mathrm{x} \mathrm{H3b}), 7.92\left(\mathrm{XX}^{\prime}\right.$ part of $\mathrm{AA}^{\prime} \mathrm{XX}^{\prime}$ pattern, $\left.2 \mathrm{H}, 2 \times \mathrm{H} 2 \mathrm{a}\right), 8.40\left(\mathrm{br} \mathrm{s}, \mathrm{W}_{\mathrm{H} / 2}=12 \mathrm{~Hz}\right.$, $2 \mathrm{H}, 2 \times \mathrm{H} 2$ ), 9.23 (br s, $\mathrm{W}_{\mathrm{H} / 2}=25 \mathrm{~Hz}, 1 \mathrm{H}, \mathrm{OH}$ ). Anal. calcd. for $\mathrm{C}_{26} \mathrm{H}_{30} \mathrm{~N}_{4} \mathrm{OBr}_{2} \mathrm{P}_{2} \mathrm{~F}_{12}$ : C, 44.33; H, 4.29; N, 7.95. Found: C, 44.33; H, 4.59; N, 7.86.

Mercury complex $\mathbf{1 0} .2 \mathrm{PF}_{6}$

A solution of $9.2 \mathrm{PF}_{6}(63 \mathrm{mg}, 81 \mu \mathrm{mol})$ and mercuric acetate $(26 \mathrm{mg}, 82 \mu \mathrm{mol})$ in anhydrous acetonitrile $(40 \mathrm{~mL})$ was heated at reflux for $24 \mathrm{~h}$. The solution was cooled and the solvent was removed under vacuum. The residue was washed with water to afford a white powder that was collected and recrystallised from hot acetonitrile to afford $\mathbf{1 0 . 2 \mathrm { PF } _ { 6 }}$ as colourless needles $(20 \mathrm{mg}$, 34\%). ${ }^{1} \mathrm{H}$ NMR (500.13 MHz, d 6 -DMSO) $\delta: ~ 1.26\left(\mathrm{~s}, 18 \mathrm{H}, 6 \times \mathrm{CH}_{3}\right), 4.92\left(\mathrm{~d},{ }^{2} J_{\mathrm{H}, \mathrm{H}}=14 \mathrm{~Hz}, 4 \mathrm{H}, 4\right.$ x CHH), $6.00\left(\mathrm{~d},{ }^{2} J_{\mathrm{H}, \mathrm{H}}=14 \mathrm{~Hz}, 4 \mathrm{H}, 4 \mathrm{x} \mathrm{CH} H\right), 7.09(\mathrm{~s}, 4 \mathrm{H}, 2 \mathrm{x} \mathrm{H} 4$ and 2 x H5), $7.49(\mathrm{~s}, 4 \mathrm{H}, 4 \mathrm{x}$ ArH), phenol $\mathrm{OH}$ not detected. ${ }^{13} \mathrm{C}$ NMR (125.77 MHz, d6-DMSO): $\delta 31.40\left(\mathrm{CH}_{3}\right), 33.55$ $\left(\mathrm{C}\left(\mathrm{CH}_{3}\right)_{3}\right), 51.97\left(\mathrm{CH}_{2}\right), 122.58(\mathrm{C} 4$ and $\mathrm{C} 5), 124.56\left(\mathrm{Ar} \mathrm{CCH}_{2}\right), 129.12(\mathrm{Ar} \mathrm{CH}), 138.40(\mathrm{Ar} C$ $\left.{ }^{t} \mathrm{Bu}\right), 157.26$ (Ar C-O), $174.44(\mathrm{C} 2)$. Anal. calcd. for $\mathrm{C}_{60} \mathrm{H}_{70} \mathrm{~N}_{8} \mathrm{O}_{4} \mathrm{Hg}_{2}\left(\mathrm{PF}_{6}\right)_{2}: \mathrm{C}, 43.46 ; \mathrm{H}, 4.25 ; \mathrm{N}$, 6.76. Found: C, 43.50; H, 4.52; N, 6.81 .

Mercury complex $\mathbf{1 0 . H g B r} 4$

A solution of 11.2Br (32 mg, $28.3 \mu \mathrm{mol})$ and mercuric acetate $(21 \mathrm{mg}, 65.9 \mu \mathrm{mol})$ in acetonitrile (4 $\mathrm{mL}$ ) was heated at reflux for $18 \mathrm{~h}$. The resulting precipitate was collected and dried under vacuum to afford a white powder (31 mg, 57\%). ${ }^{1} \mathrm{H}$ NMR (500.13 MHz, d6-DMSO): $\delta 1.26$ (s, 36H, $12 \mathrm{x}$ 
$\left.\mathrm{CH}_{3}\right), 4.89\left(\mathrm{~d},{ }^{2} J_{\mathrm{HH}}=14 \mathrm{~Hz}, 8 \mathrm{H}, 8 \times \mathrm{CHH}\right), 6.04\left(\mathrm{~d},{ }^{2} J_{\mathrm{HH}}=14 \mathrm{~Hz}, 8 \mathrm{H}, 8 \times \mathrm{CH} H\right), 7.04(\mathrm{~s}, 8 \mathrm{H}, 4 \mathrm{x}$ H4 and 4 x H5), 7.45 (s, 8H, 8 x ArH). ${ }^{13} \mathrm{C}$ NMR (125.76 MHz, d6-DMSO): $\delta 33.49\left(\mathrm{CH}_{3}\right), 33.48$ $\left(C\left(\mathrm{CH}_{3}\right)_{3}\right), 51.94\left(\mathrm{CH}_{2}\right), 122.37(\mathrm{C} 4$ and $\mathrm{C} 5), 124.58\left(\mathrm{Ar} \mathrm{CCH}_{2}\right), 128.79(\mathrm{Ar} \mathrm{CH}), 138\left(\mathrm{Ar} C-{ }^{t} \mathrm{Bu}\right)$, 158 (Ar CO), 175.46 (C2). HRMS (FAB) m/z: $163.4703\left(\mathrm{C}_{60} \mathrm{H}_{68} \mathrm{~N}_{4} \mathrm{O}_{4}{ }^{199} \mathrm{Hg}^{200} \mathrm{Hg}[\mathrm{M}-\mathrm{HgBr} 4-\mathrm{H}]\right.$ requires 1363.4730), $1364.4781\left(\mathrm{C}_{60} \mathrm{H}_{68} \mathrm{~N}_{4} \mathrm{O}_{4}{ }^{199} \mathrm{Hg}^{201} \mathrm{Hg}\left[\mathrm{M}-\mathrm{HgBr}_{4}-\mathrm{H}\right]\right.$ requires 1364.4749), 1365.4791 $\left(\mathrm{C}_{60} \mathrm{H}_{68} \mathrm{~N}_{4} \mathrm{O}_{2}{ }^{199} \mathrm{Hg}^{202} \mathrm{Hg} \quad\left[\mathrm{M}-\mathrm{HgBr}_{4}-\mathrm{H}\right]\right.$ requires 1365.4753). Anal. calcd. for $\mathrm{C}_{60} \mathrm{H}_{70} \mathrm{~N}_{8} \mathrm{O}_{4} \mathrm{Hg}_{3} \mathrm{Br}_{4}:$ C, 38.16; H, 3.74; N, 5.93. Found: C, 38.04; H, 4.19; N, 5.17.

Structure determinations

The general procedure is described in a preceding paper [15], but with the following minor variations. In $10 . \mathrm{HgBr}_{4} .8 \mathrm{DMF}$, two t-butyl groups, one coordinated $\mathrm{DMF}$ and one solvent $\mathrm{DMF}$ were modelled as disordered over two sets of sites. In $10.2 \mathrm{PF}_{6} .5 \mathrm{MeCN}$, two t-butyl groups were modelled as disordered, as also was one of the $\mathrm{PF}_{6}{ }^{-}$anions. Phenolic hydrogen atoms could not be sensibly located, there being no outstanding differences in C-O parameters or environments, and they were omitted from the refinement. Pertinent results are given in the Tables, text and Fig. 2, the latter showing non-hydrogen atom displacement envelopes at the $50 \%$ probability amplitude level. Full .cif depositions for both structures reside with the Cambridge Structural Database, CCDC $1038211,1038212$.

Acknowledgments We thank the Australian Research Council for financial support (DP0344334 to M.V.B., A.H.W.) and an Australian Postgraduate Award (to V.J.H.). We acknowledge the Centre of Microscopy, Characterisation and Analysis, The University of Western Australia (a facility 
funded by The University of Western Australia, the Australian Government and the State Government of Western Australia) for providing access to facilities, and for scientific and technical assistance.

Conflict of Interest: The authors declare that they have no conflict of interest.

\section{References}

1. Yuan, D., Huynh, H. V.: Syntheses and characterizations of thiolato-functionalized $N$ heterocyclic carbene Pd(II) complexes with normal and mesoionic binding modes. Dalton Trans. 40, 11698-11703 (2011)

2. Bernhammer, J. C., Huynh, H. V.: Nickel(II) benzimidazolin-2-ylidene complexes with thioether- functionalized side chains as catalysts for Suzuki-Miyaura cross-coupling. Organometallics 33, 5845-5851 (2014)

3. Bernhammer, J. C., Huynh, H. V.: Benzimidazolin-2-ylidene complexes of palladium(II) featuring a thioether moiety: synthesis, characterization, molecular dynamics, and catalytic activities. Organometallics 33, 1266-1275 (2014)

4. Jiménez, M. V., Fernández-Tornos, J., Pérez-Torrente, J. J., Modrego, F. J., Winterle, S., Cunchillos, C., Lahoz, F. J., Oro, L. A.: Iridium(I) complexes with hemilabile $N$ heterocyclic carbenes: efficient and versatile transfer hydrogenation catalysts. Organometallics 30, 5493-5508 (2011)

5. Guo, L., Song, X.-Z., Lin, C.-X., Li, Q.-S., Liu, C., Wang, W.-H., Xu, F.-B.: Synthesis of multi-imidazolium salt ligands containing calixarene fragments and their $N$-heterocyclic carbene $\operatorname{Ag}(\mathrm{I})$ macrocyclic complexes. Polyhedron 85, 732-739 (2015)

6. Arnold, P. L., Scarisbrick, A. C.: Di- and trivalent ruthenium complexes of chelating, anionic $N$-heterocyclic carbenes. Organometallics 23, 2519-2521 (2004) 
7. Arnold, P. L., Rodden, M., Davis, K. M., Scarisbrick, A. C., Blake, A. J., Wilson, C.: Asymmetric lithium(I) and copper(II) alkoxy- $N$-heterocyclic carbene complexes; crystallographic characterisation and Lewis acid catalysis. Chem. Commun. 1612-1613 (2004)

8. Deng, H.-n., Xing, Y.-1., Xia, C.-1., Sun, H.-m., Shen, Q., Zhang, Y.: Ionic iron(III) complexes of bis(phenol)-functionalized imidazolium cations: synthesis, structures and catalysis for aryl Grignard cross-coupling of alkyl halides. Dalton Trans. 41, 11597-11607 (2012)

9. Zhang, M., Ni, X., Shen, Z.: Synthesis of bimetallic bis(phenolate) $N$-heterocyclic carbene lanthanide complexes and their applications in the ring-opening polymerization of $\mathrm{L}$ lactide. Organometallics 33, 6861-6867 (2014)

10. Waltman, A. A., Grubbs, R. H.: A new class of chelating $N$-heterocyclic carbene ligands and their complexes with palladium. Organometallics 23, 3105-3107 (2004)

11. Aihara, H., Matsuo, T., Kawaguchi, H.: Titanium $N$-heterocyclic carbene complexes incorporating an imidazolium-linked bis(phenol). Chem. Commun. 2204-2205 (2003)

12. Li, W.-F., Sun, H.-M., Wang, Z.-G., Chen, M.-Z., Shen, Q., Zhang, Y.: Synthesis and structural characterization of aryloxo-functionalized $N$-heterocyclic carbene complexes of nickel(II). J. Organomet. Chem. 690, 6227-6232 (2005)

13. Mas-Marzá, E., Poyatos, M., Sanaú, M., Peris, E.: A new rhodium(III) complex with a tripodal bis(imidazolylidene) ligand. Synthesis and catalytic properties. Organometallics 23, 323-325 (2004)

14. Baker, M. V., Brown, D. H., Haque, R. A., Simpson, P. V., Skelton, B. W., White, A. H., Williams, C. C.: Mercury complexes of $N$-heterocyclic carbenes derived from imidazoliumlinked cyclophanes: synthesis, structure, and reactivity. Organometallics 28, 3793-3803 (2009) 
15. Hesler, V. J., Skelton, B. W., White, A. H., Brown, D. H., Baker, M. V .: Calixarene/azolium cyclophane hybrids: synthesis, structure and conformations. J. Incl. Phenom. Macrocycl. Chem., DOI 10.1007/s10847-015-0491-1 (2015)

16. Baker, M. V., Bosnich, M. J., Brown, D. H., Byrne, L. T., Hesler, V. J., Skelton, B. W., White, A. H., Williams, C. C.: Azolium-linked cylophanes: a comprehensive examination of conformations by ${ }^{1} \mathrm{H}$ nmr spectroscopy and structural studies. J. Org. Chem. 69, 7640-7652 (2004)

\section{Figure and Scheme captions}

Scheme 1 Compounds $1.4 \mathrm{PF}_{6}-9.2 \mathrm{Br}$

Scheme 2 Synthesis of the binuclear Hg-NHC complex 10

Scheme 3 The salts $11.2 \mathrm{Br}$ and $12.2 \mathrm{PF}_{6}$

Fig. $1{ }^{1} \mathrm{H}$ NMR spectra (500 MHz, ambient temperature) for: a, a solution of $9.2 \mathrm{PF}_{6}$ in DMSO-d 6 ,

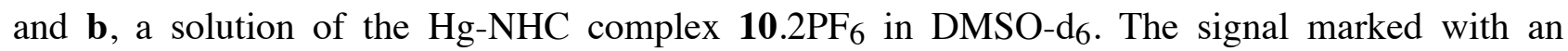
asterisk $(*)$ is due to traces of solvent impurity $\left(\mathrm{CH}_{3} \mathrm{CN}\right.$, reaction solvent). Signals at 2.5 and $\sim 3.3$ ppm are due to residual solvent protons $\left(D M S O-d_{5}\right)$ and adventitious moisture respectively. Signals marked with a tilde $(\sim)$ have been cropped for clarity.

Fig. 2 a Projection of the binuclear cation 1 of $10.2 \mathrm{PF}_{6} \cdot 5 \mathrm{MeCN}$

Fig. 2 b Projection of the binuclear cation of $10 . \mathrm{HgBr}_{4} \cdot 8 \mathrm{DMF}$, together with the approaches of the anion and the 'coordinating' pair of DMF solvent molecules. One of the possible dispositions of the phenolic protonating hydrogen atoms is shown. 
Scheme 1 Compounds 1.4PF $6-9.2 \mathrm{Br}$

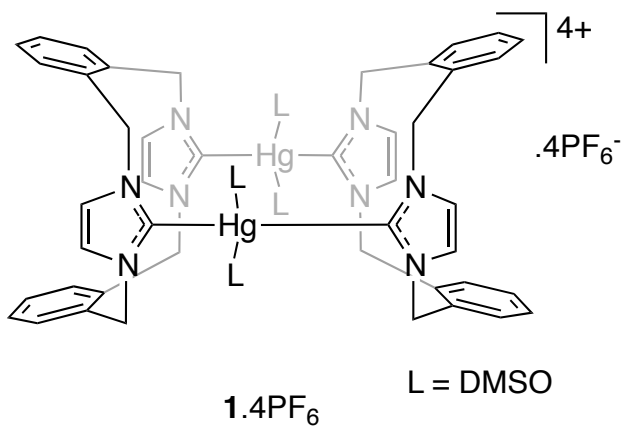

$.4 \mathrm{PF}_{6}$

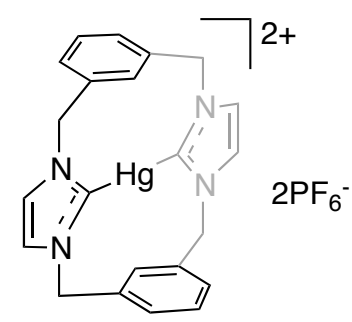

2. $2 \mathrm{PF}_{6}$

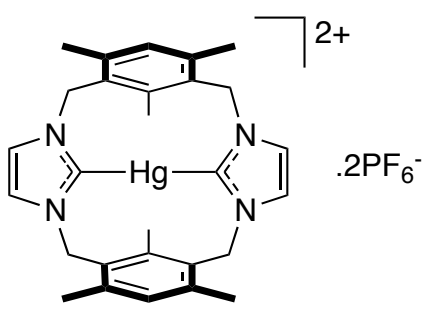

3. $2 \mathrm{PF}_{6}$

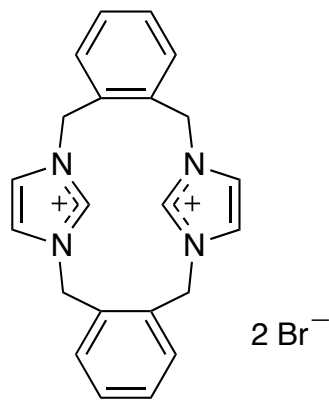

$5.2 \mathrm{Br}$

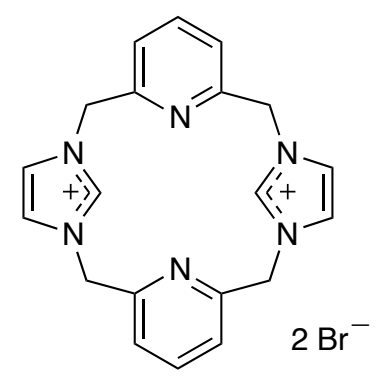

8. $2 \mathrm{Br}$

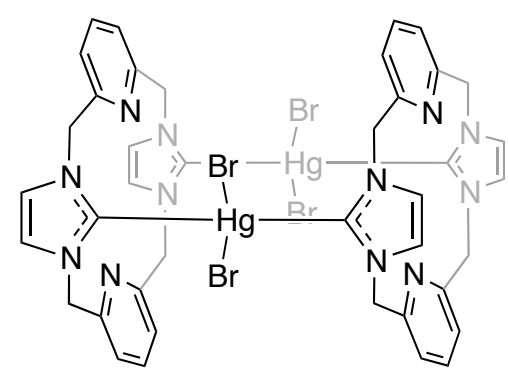

4

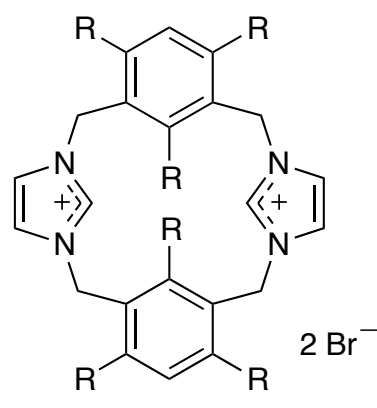

6.2Br $\mathrm{R}=\mathrm{H}$

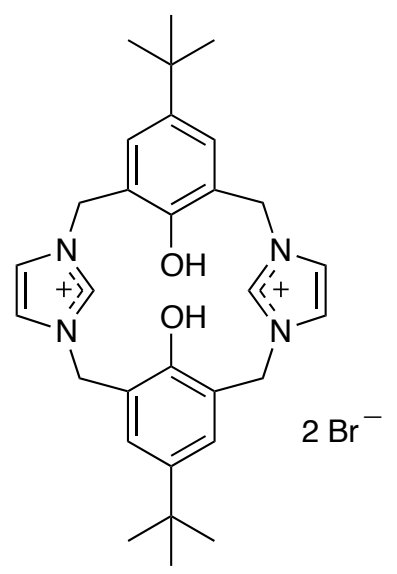

$9.2 \mathrm{Br}$ 
Scheme 2 Synthesis of the binuclear Hg-NHC complex 10

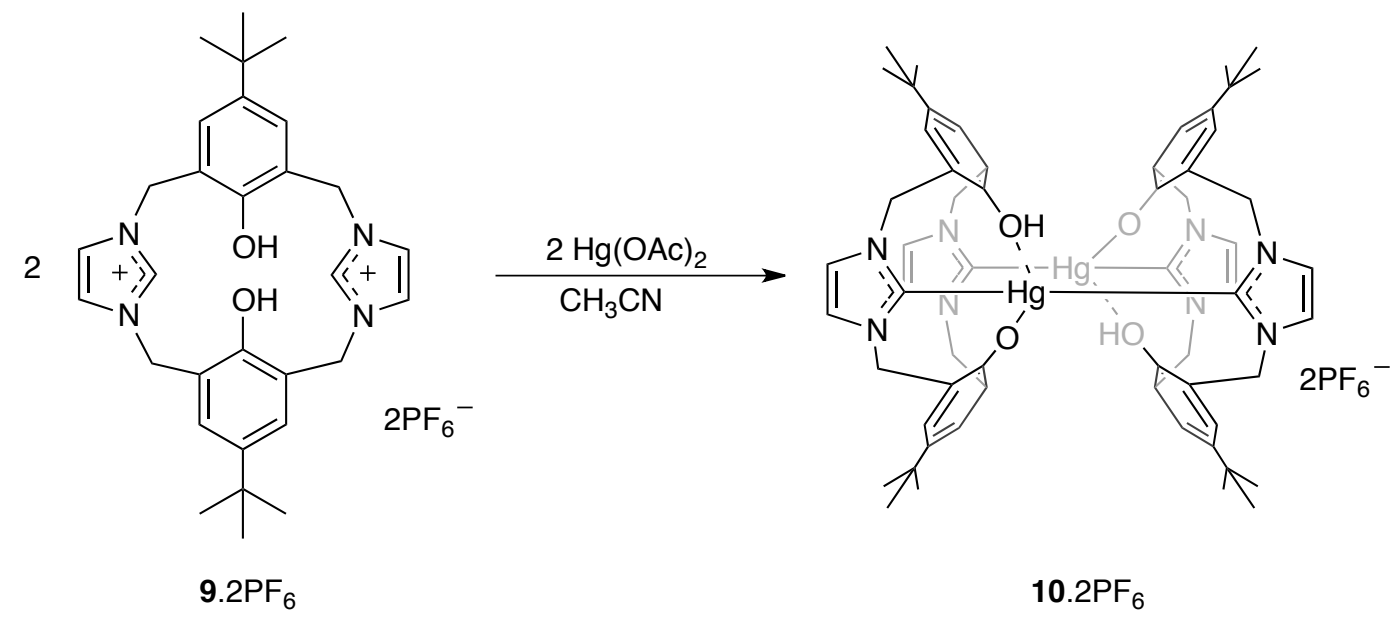

Scheme 3 The salts $11.2 \mathrm{Br}$ and $12.2 \mathrm{PF}_{6}$

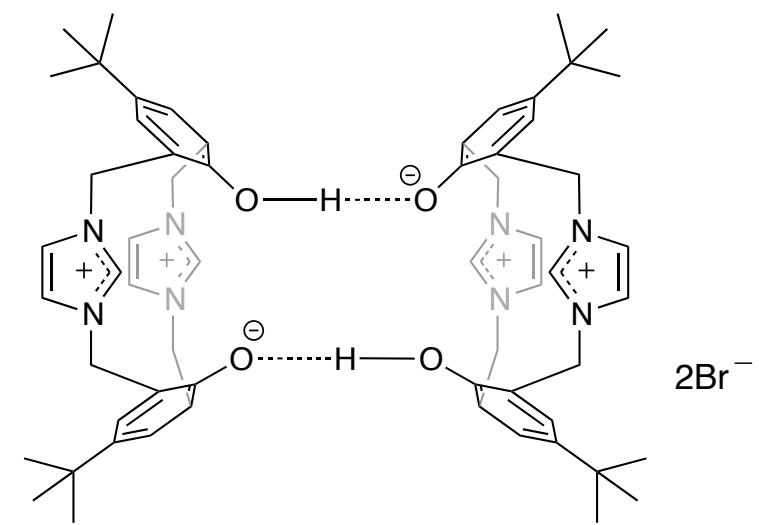

$11.2 \mathrm{Br}$

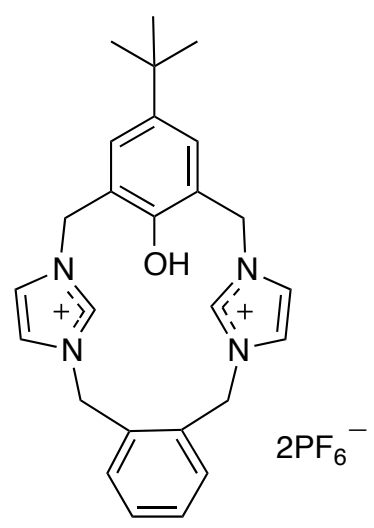

12. $2 \mathrm{PF}_{6}$ 


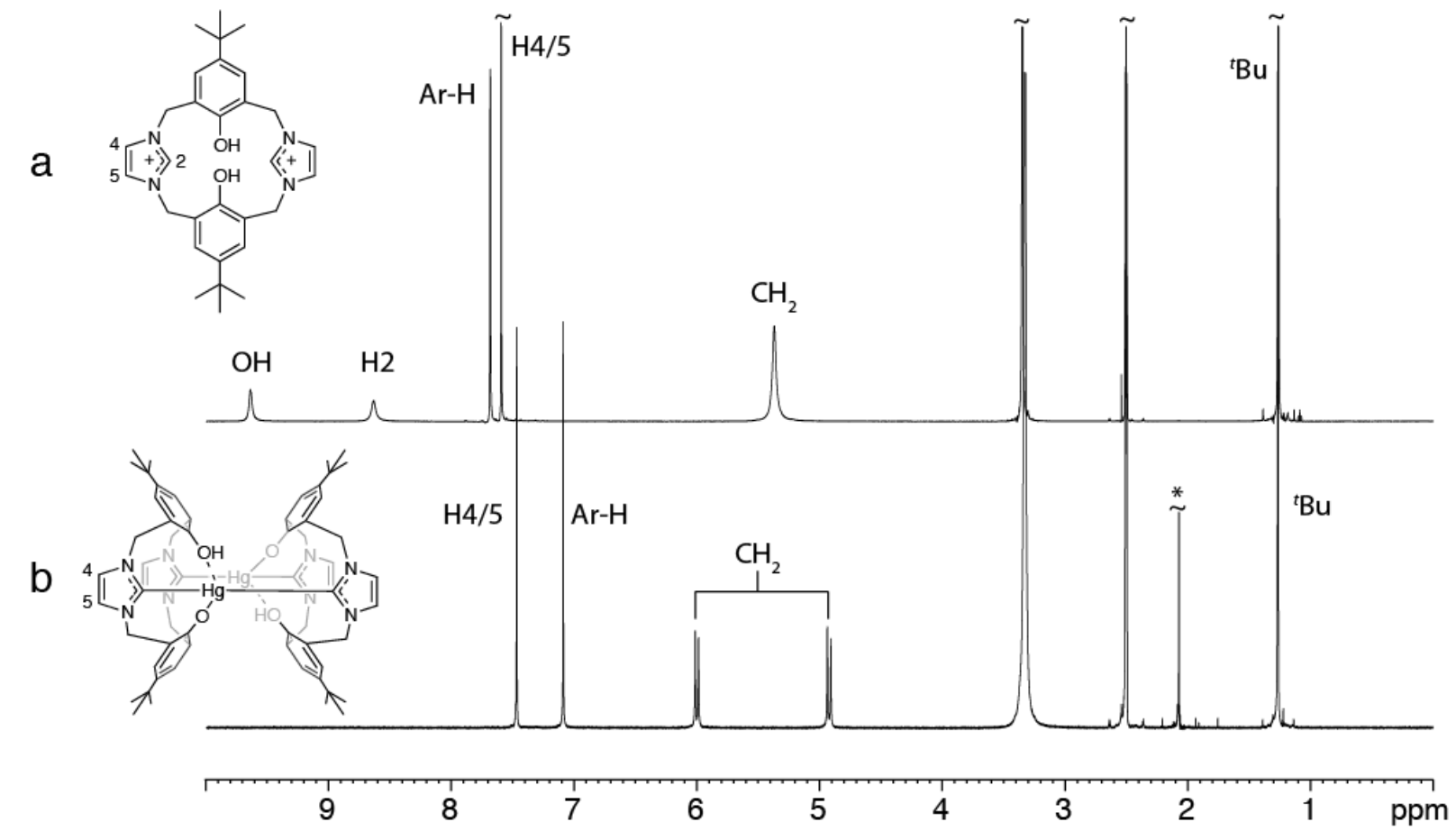

Fig. $1{ }^{1} \mathrm{H}$ NMR spectra (500 MHz, ambient temperature) for: a, a solution of 9.2PF 6 in DMSO-d 6 , and $\mathbf{b}$, a solution of the $\mathrm{Hg}-\mathrm{NHC}$ complex $\mathbf{1 0 . 2 P F}_{6}$ in $\mathrm{DMSO}_{6}$. The signal marked with as asterisk (*) is due to traces of solvent impurity $\left(\mathrm{CH}_{3} \mathrm{CN}\right.$, reaction solvent). Signals at 2.5 and $~ 3.3$ ppm are due to residual solvent protons $\left(D M S O-d_{5}\right)$ and adventitious moisture respectively. Signals marked with a tilde $(\sim)$ have been cropped for clarity. 


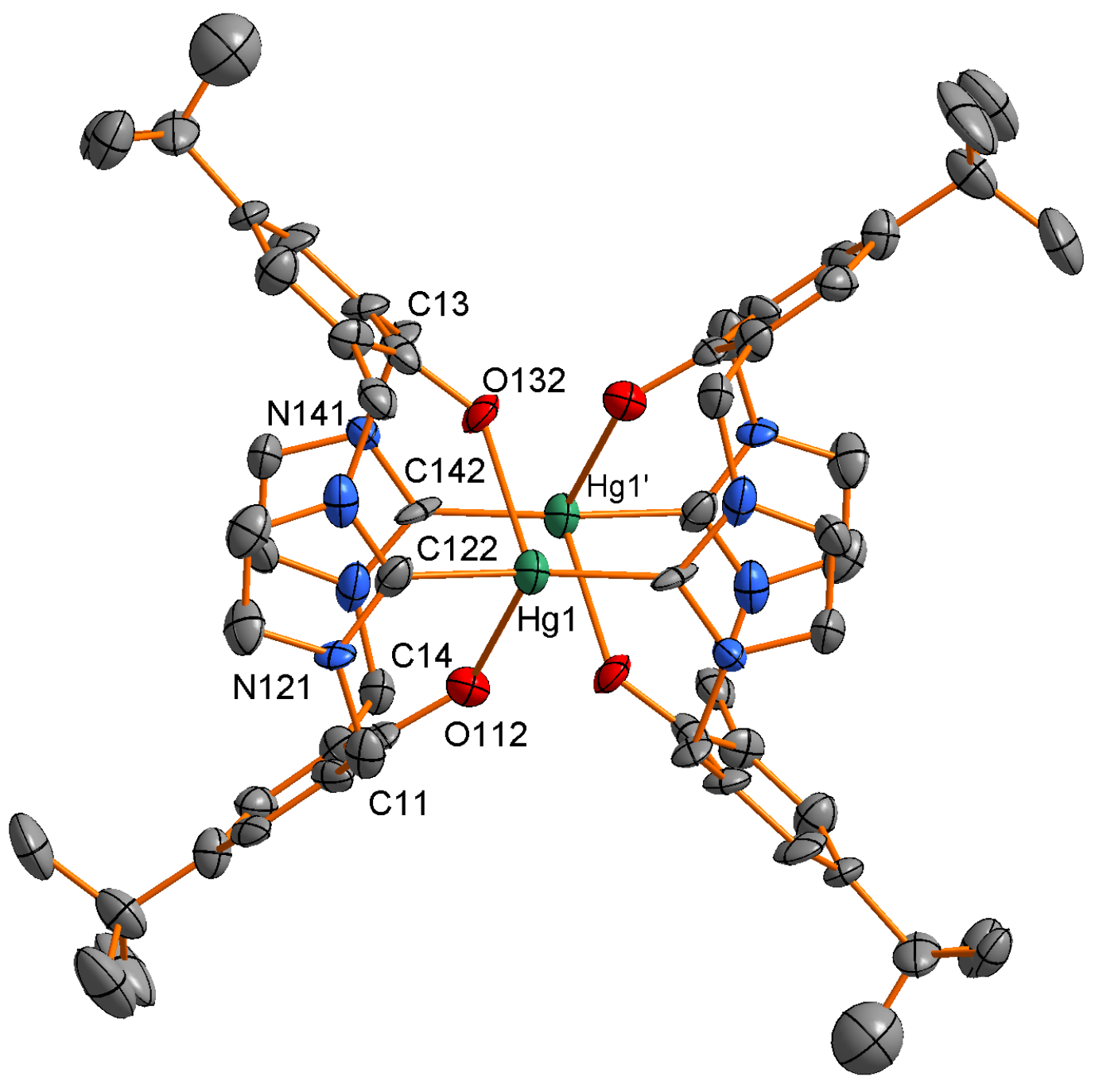

Fig. 2 a Projection of binuclear cation 1 of $10.2 \mathrm{PF}_{6} \cdot 5 \mathrm{MeCN}$ 


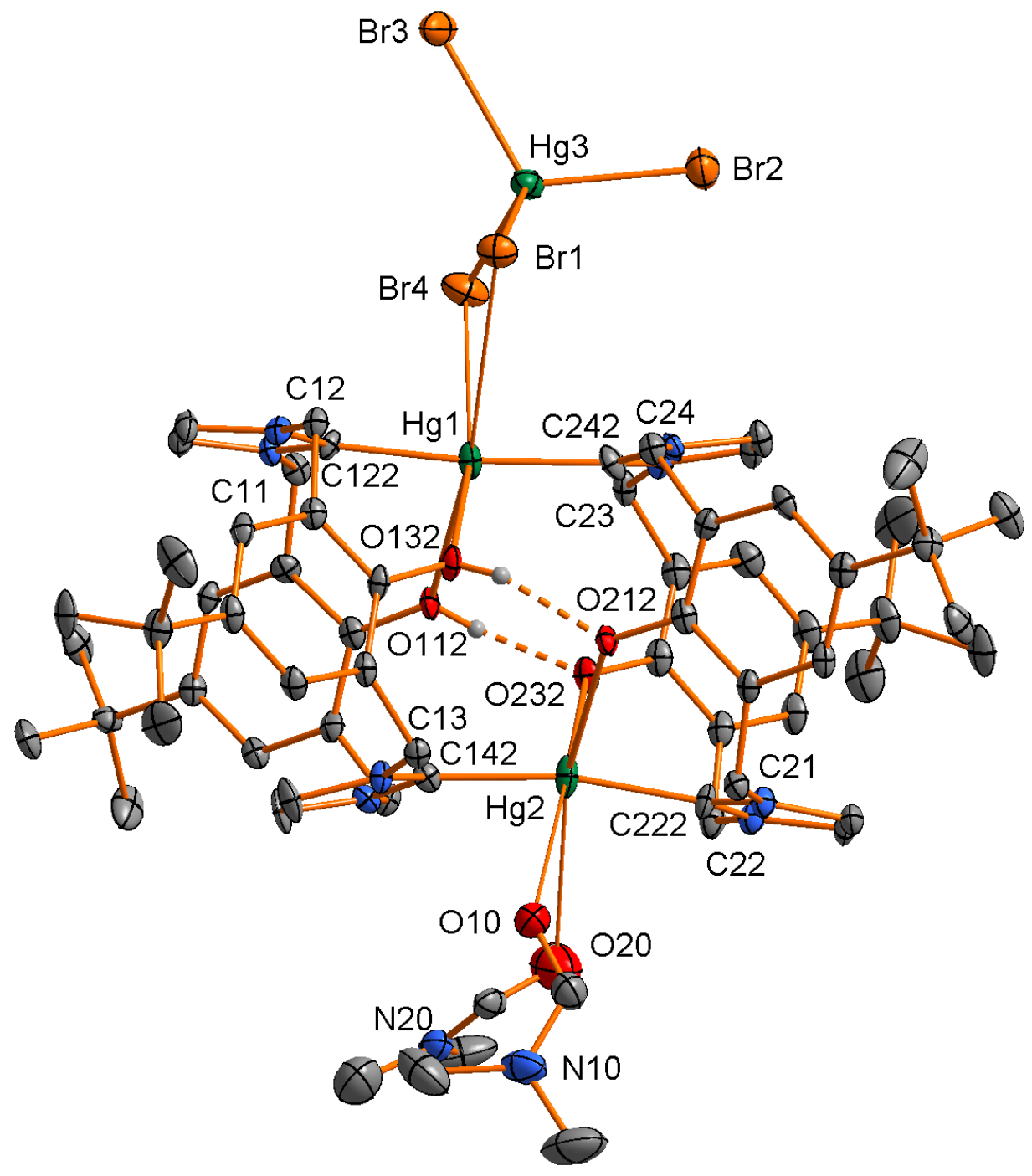

Fig. 2 b Projection of the binuclear cation of $10 . \mathrm{HgBr}_{4} \cdot 8 \mathrm{DMF}$, together with the approaches of the anion and the 'coordinating' pair of DMF solvent molecules. 
Table 1 Crystal/refinement data

\begin{tabular}{|c|c|c|}
\hline & 10. $2 \mathrm{PF}_{6} \cdot 5 \mathrm{MeCN}$ & 10. $\mathrm{HgBr}_{4} \cdot 8 \mathrm{DMF}$ \\
\hline Formula & $\mathrm{C}_{70} \mathrm{H}_{85} \mathrm{~F}_{12} \mathrm{Hg}_{2} \mathrm{~N}_{13} \mathrm{O}_{4} \mathrm{P}_{2}$ & $\mathrm{C}_{84} \mathrm{H}_{126} \mathrm{Br}_{4} \mathrm{Hg}_{3} \mathrm{~N}_{16} \mathrm{O}_{12}$ \\
\hline $\mathbf{M}_{r}$ & 1863.6 daltons & 2473.4 daltons \\
\hline Crystal system & Triclinic & Monoclinic \\
\hline Space group & $P \overline{1}\left(C_{i}^{1}\right.$, No. 2$)$ & $P 2_{1} / n\left(C_{2 h}^{5}\right.$, No. 14$)$ \\
\hline \multirow[t]{6}{*}{ Unit cell } & $a=13.438(1) \AA$ & $a=14.308(3) \AA$ \\
\hline & $b=14.306(1) \AA$ & $b=25.731(5) \AA$ \\
\hline & $c=21.398(1) \AA$ & $c=26.257(5) \AA$ \\
\hline & $\alpha=88.364(7)^{\circ}$ & $\alpha=90^{\circ}$ \\
\hline & $\beta=72.578(7)^{\mathrm{o}}$ & $\beta=91.597(3)^{\mathrm{o}}$ \\
\hline & $\gamma=89.442(8)^{\circ}$ & $\gamma=90^{\circ}$ \\
\hline$V$ & $3923.3(5) \AA^{3}$ & $9666(3) \AA^{3}$ \\
\hline Density $(Z)$ & 1.578 Mg.m $\mathrm{m}^{-3}$ (2 f.u.) & $1.700 \mathrm{Mg} \cdot \mathrm{m}^{-3}$ (4 f.u.) \\
\hline$\mu_{\mathrm{Mo}}\left(' T_{\min / \max }\right)$ & $4.0 \mathrm{~mm}^{-1}(0.87)$ & $6.5 \mathrm{~mm}^{-1}(0.51)$ \\
\hline Specimen & $0.142 \times 0.048 \times 0.042 \mathrm{~mm}^{3}$ & $0.52 \times 0.12 \times 0.10 \mathrm{~mm}^{3}$ \\
\hline $2 \theta_{\max }\left(N_{\mathrm{t}}\right)$ & $50^{\circ}(33774)$ & $58^{\circ}(89112)$ \\
\hline$N\left(R_{\text {int }}\right)$ & $13710(0.092)$ & $23917(0.069)$ \\
\hline$N_{\mathrm{o}}(I>2 \sigma(I))$ & 5414 & 15921 \\
\hline$R_{1}(S)$ & $0.048(0.70)$ & $0.061(1.08)$ \\
\hline$w R_{2}(\mathrm{a}(, \mathrm{b}))$ & $0.074(0.013,-)$ & $0.162(0.063,67)$ \\
\hline$|\Delta \rho|_{\max }$ & $1.32 \mathrm{e}^{-3}$ & $4.5 \mathrm{e}^{-3}$ \\
\hline
\end{tabular}


Table 2 Selected mercury atom environments in $10.2 \mathrm{PF}_{6} \cdot 5 \mathrm{MeCN}$ and $\mathbf{1 0} \cdot \mathrm{HgBr}_{4} \cdot 8 \mathrm{DMF}$

\begin{tabular}{|c|c|c|c|c|}
\hline & \multicolumn{2}{|c|}{ 10. $2 \mathrm{PF}_{6} \cdot 5 \mathrm{MeCN}$} & \multicolumn{2}{|c|}{ 10. $\mathrm{HgBr}_{4} \cdot 8 \mathrm{DMF}$} \\
\hline & Cation 1 & Cation 2 & $\operatorname{Hg}(1)$ & $\operatorname{Hg}(2)$ \\
\hline \multicolumn{5}{|c|}{ Distances $(\AA)$} \\
\hline $\mathrm{Hg}-\mathrm{C}$ & $2.034(9)$ & $2.027(9)$ & $2.050(7)$ & $2.074(8)$ \\
\hline $\mathrm{Hg}-\mathrm{C}^{\prime}$ & $1.997(9)$ & $2.028(8)$ & $2.075(9)$ & $2.035(8)$ \\
\hline $\mathrm{Hg}-\mathrm{O}$ & $2.578(5)$ & $2.625(6)$ & $2.673(5)$ & $2.633(5)$ \\
\hline $\mathrm{Hg}-\mathrm{O}^{\prime}$ & $2.632(5)$ & $2.633(5)$ & $2.732(5)$ & $2.649(5)$ \\
\hline $\mathrm{Hg} \ldots \mathrm{Hg}^{\prime}$ & $4.7208(6)$ & $4.8082(6)$ & $4.8127(12)$ & \\
\hline $\mathrm{O} \ldots \mathrm{O}^{\prime}$ & $2.502(8)$ & $2.486(8)$ & $2.499(8)$ & $2.532(8)$ \\
\hline \multicolumn{5}{|c|}{ Angles (degrees) } \\
\hline C-Hg-C' & 167.4(3) & $171.8(3)$ & $174.5(3)$ & $169.3(3)$ \\
\hline $\mathrm{O}-\mathrm{Hg}-\mathrm{O}$ & $94.4(2)$ & $92.5(2)$ & $93.7(2)$ & $94.3(2)$ \\
\hline $\mathrm{O}-\mathrm{Hg}-\mathrm{C}$ & $87.1(3)$ & $88.2(3)$ & $84.1(2)$ & $76.8(3)$ \\
\hline $\mathrm{O}-\mathrm{Hg}-\mathrm{C}^{\prime}$ & $100.4(3)$ & $98.4(3)$ & $99.1(3)$ & $99.7(3)$ \\
\hline $\mathrm{O}-\mathrm{Hg}-\mathrm{C}$ & 87.1(3) & $85.7(3)$ & $85.5(2)$ & 89.1(3) \\
\hline $\mathrm{O}-\mathrm{Hg}-\mathrm{C}^{\prime}$ & $102.3(3)$ & $98.8(2)$ & $98.8(2)$ & $100.7(3)$ \\
\hline
\end{tabular}

In the $\mathrm{PF}_{6}^{-}$salt, in each binuclear cation there are two centrosymmetrically related mercury atoms; primed atoms belong to the other ligand/other half of the cation. About $\mathrm{Hg}(3)$ in the $\mathrm{HgBr}_{4}{ }^{2-}$ anion, $\mathrm{Hg}-\mathrm{Br}$ range between 2.5940(11)-2.6076(13) $\AA$, and $\mathrm{Br}-\mathrm{Hg}-\mathrm{Br} 106.23(4)-103.96(4)^{\mathrm{o}} ; \mathrm{Hg}(3) \ldots \mathrm{Hg}(1)$ is 4.1364(10) $\AA$, and $\mathrm{Hg}(1) \ldots \mathrm{Br}(1,4) 3.5448(12), 3.5208(14) \AA . \operatorname{Hg}(2) \ldots \mathrm{O}(\operatorname{dmf}(1,2))$ are 3.129(8), 3.121(11) $\AA$. In the $\mathrm{PF}_{6}{ }^{-}$salt, $\mathrm{Hg}-\mathrm{O}-\mathrm{C}$ range between $132.7(5)-134.4(5)^{\mathrm{o}}$, and in the $\mathrm{HgBr}_{4}{ }^{2-}$ salt $132.0(5)-134.8(4)^{\circ}$. 
Table 3 Ligand plane parameters

\begin{tabular}{|c|c|c|c|c|c|}
\hline \multicolumn{2}{|c|}{ Ring } & \multicolumn{2}{|l|}{ 10.2PF $6.5 \mathrm{MeCN}$} & \multicolumn{2}{|c|}{$\mathbf{1 0 .} \mathrm{HgBr}_{4} \cdot 8 \mathrm{DMF}$} \\
\hline \multicolumn{6}{|c|}{ (a) Mercury atom out-of-plane distances $(\AA)$} \\
\hline & & $\operatorname{Hg}(1)$ & $\operatorname{Hg}(2)$ & $\operatorname{Hg}(1)$ & $\operatorname{Hg}(2)$ \\
\hline \multicolumn{2}{|c|}{$\mathrm{C}_{3} \mathrm{~N}_{2}(12)$} & $0.16(2),-$ & $-\quad$, & $0.066(14)$ & - \\
\hline & (14) & $-\quad, 0.24(2)$ & , & - & $0.394(15)$ \\
\hline & $(22)$ &,$\quad-$ & $0.29(2)$ & - & $0.051(15)$ \\
\hline & $(24)$ &,$\quad-$ & $-\quad, 0.25(2)$ & $0.29(2)$ & - \\
\hline \multirow[t]{4}{*}{$\mathrm{C}_{6}$} & $(11)$ & $0.86(2), 0.73(2)$ & $0.65(2), 0.78(2)$ & $0.82(2)$ & $0.80(2)$ \\
\hline & (13) & $0.67(2), 0.74(2)$ & $0.65(2), 0.61(2)$ & $0.95(2)$ & $1.16(2)$ \\
\hline & $(21)$ &,$\quad-$ & - & $0.75(2)$ & $0.75(2)$ \\
\hline & $(23)$ & , & - & $10.2(2)$ & $0.96(2)$ \\
\hline
\end{tabular}

(b) Interplanar dihedral angles (degrees)

(i) $\mathrm{C}_{3} \mathrm{~N}_{2}$ imidazole planes

$\begin{array}{lllll} & \text { ligand (1) } & \text { ligand (2) } & \text { ligand (1) } & \text { ligand (2) } \\ \mathrm{n} 2 / \mathrm{n} 4 & 14.2(4) & 7.2(4) & 16.2(4) & 16.3(4)\end{array}$

(ii) $\mathrm{C}_{6}$ aromatic planes

$\begin{array}{lllll} & \text { ligand (1) } & \text { ligand (2) } & \text { ligand (1) } & \text { ligand (2) } \\ \mathrm{n} 1 / \mathrm{n} 3 & 77.1(4) & 80.7(3) & 71.8(3) & 73.2(3)\end{array}$

For the $\mathrm{PF}_{6}^{-}$salt, italicized values are symmetry related; in the monoprotonated cyclophane system 11.2Br.4MeCN [15], devoid of mercury atoms, but with similar confronting pairs of ligands with oxygen atoms linked by hydrogen bonds, $\left(\mathrm{O}(-\mathrm{H}) \ldots \mathrm{O}^{\prime} 2.445(2) \AA\right)$ ), the im/im and Ar/Ar interplanar dihedral angles are 69.21(8), 78.84(6) ${ }^{\circ}$. 